\title{
Enhancement of Technology from Old Preservatives to New Preservatives and Latest Development in the Field of Preservation
}

\author{
Sonia Panigrahi ${ }^{1 *}$ and Sadhna Tripathy ${ }^{2}$ \\ ${ }^{1}$ M.S.Swaminathan School of Agriculture, CUTM, Paralakhemundi-761200(Odisha), India \\ ${ }^{2}$ Forest Product Division, Forest Research Institute, Dehradun- 248195, India \\ *Corresponding author
}

\section{A B S T R A C T}

Keywords

Chromated Copper Arsenate (CCA), Acza, Electro pulsing technology, Creosote oil

Article Info

Accepted:

14 December 2018 Available Online: 10 January 2019

\begin{abstract}
Wood preservatives are usually protecting the wood products from deterioration. Various methods of treatment can be practiced to incorporate the preservatives inside the wood depending upon the application of end product. Ultimately the preservative enhance the dimensional properties and provide resistance to wood products from biological pathogens. Improvement in the present situation of wood preservation in tropical countries would result in a great reduction of wood losses. Losses resulting from lack of preservation are strikingly high compared with the costs of preservation. Chemical and thermal modification are the most popular method of treatment from 20th century. The greatest impact on wood preservation in the 20th century is the invention of Chromated copper arsenate (CCA) preservatives which is gaining a lot of attention afterwards. The preservative used earlier are oily liquid preservatives like creosite, creosote oil and coal tar, petroleum but application of modern technology in the latest developed preservatives have grate efficiency over the earlier.
\end{abstract}

\section{Introduction}

Wood preservation was first introduced as an industrial process in England and it has continued to be used in situation where decay is otherwise inevitable such as for railway sleepers and transmission pole. It must be accepted that wood decay is inevitable for example- fungal decay is dependent on moisture content, so that a structure designed to maintain wood in a dry condition is sufficient to ensure freedom from fungal decay, whatever the species of wood. The preservative treatment required in wood to increase the lifespan of the material and reduce the replacement of the material. But preservation involves additional cost and must clearly be justified. The environmentalist may see preservation as a mean for reducing our demand for replacement wood, thus conserving our forest. Wood importing countries will wish to reduce wood import as to reduce currency while the wood exporting countries will adopt preservation in order to reduce home demand for replacement wood, thus leaving the maximum volume available for export. Wood preservation is the pressure or thermal impregnation of chemicals into 
wood to a depth that will provide effective long-term resistance to attack by fungi, insects and marine borers. By extending the service life of timber, wood preservation reduces the harvest of valuable forestry resources, reduces operating costs in industries such as utility and railroads, and ensures safe conditions where timbers are used as support structures. In addition to industrial and commercial application, a significant part of the treated wood volume is used for residential construction to protect homeowners' investments and provide outdoor living spaces that are a desired part of the Canadian way of living. As indicated earlier, these costs show that the average cost of wood preservation in tropical countries may amount to about 20 to 30 percent of the cost of the timber used and that the service life of treated wood may be 5 or more times as long (Swiderski, 1997). The use of preservative chemicals and treated wood has been and still is sometimes criticized on the basis of health or environmental concerns. Ignorance on the part of the treating industry, poor work practices and lax environmental regulation all share part of the blame for that negative perception. Innovation in the first half of the 20th century led to the development of more effective wood protecting chemicals and processing techniques that turned a specialty industry into a commodity business (Preston, 2000). As can happen in all commodity businesses, research and development was not sustained when profit margins began to fall and the door was opened for competitive products such as plastics, concrete and steel (Kevin Archer and Stan Lebow, 2006).

\section{About wood preservatives}

Some species are naturally durable as the Sapwood is rarely durable, the heartwood of many tree species exhibits some degree of resistance to attack by decay fungi and insects, This natural durability can be attributed to a combination of toxic extractives present in the wood and low inherent permeability. As a result of this natural durability such woods can be used outdoors and in some cases in ground contact or submersed in water. Wood from naturally durable species is sometimes viewed as being environmentally preferable to chemically treated wood, and many of these species have an attractive appearance. In addition, some species such as black locust, greenheart and ipe also have excellent strength properties (Green et al., 1999). As might be expected such a combination of desirable attributes has led to increasing interest in use of durable species from the tropical countries for construction in North America and Europe. However, several factors limit the use of naturally durable species. In developed countries the volume of growing stock of naturally durable species is relatively low compared to the demand for dur able wood products.(www..fpl.fs.fed.us/docu mnts/pdf2006/fpl_2006_archer001.pdf). In view of the limited supply of natural durable wood species, it is valuable to supply of less durable wood treated with preservatives. Preservatives treatment of timber therefore it is important to conserve the wood sources of the country.

Wood preservatives are chemical substances that when suitably applied to wood, make it resistance to fungi, insect and woodborer. There are two general classes of wood preservatives: oils, such as creosote and petroleum solutions of pentachlorophenol; and waterborne salts that are applied as water solutions. The effectiveness of the preservatives varies greatly and can depend not only upon its composition, but also upon the quantity injected into the wood, the depth of penetration, and the conditions to which the treated material is exposed in service (Wood Preserving Industry Production Statistical Report, 1996). 
The choice of wood preservatives depends upon the character of the wood to be treated, the anticipated service and the properties of the chemical or formulation. Wood preservation formulations must:

protect against attacking organisms;

be able to penetrate wood;

remain in the wood for the length of the intended service;

be chemically stable;

be safe to handle;

be economical to use; preservatives are two types either oily liquids or metallic compounds.

Major used wood preservatives are:-

Pentachlorophenol

Creosote

Inorganic salts

Amonical cupper arsenate

Chromate cupper arsenate- Acid cupper chromate

Chromate zinc chloride

Minor used wood preservatives

Copper naphthenate

Copper 8

Tributyltin oxide

New preservatives

Alkylammonium compounds(AAC)

Di -alkyl dimethyl ammonium

Advantages of wood preservatives are clean, colourless, odourless and paintable. They should not cause more than minimal swelling.

A wood preservatives must be toxic to the insect, pest, fungi, borer. It must be able to be absorbed and held by the wood so that it does not leach out into the environment. The ingredients of most preservatives are potent, capable of causing poisoning as small as a few drops or few grams.

\section{Preservatives used earlier}

In Europe the first attempt were taken by placing of stone blocks under wooden pillars to keep away soil and vegetation.

Later on olive oil or other essential oil were used as they kept the wood free from insect attack.

M. Paulet in his book entitled "conservation des Bios" enumerates 173 processes or methods that were tried, most of which proved unsuccessful. It was during the $1^{\text {st }}$ quadrate of the $19^{\text {th }}$ century that modern methods of injecting wood may be considered as beginning although the most successful attempts did not come until a few years later.

Mercuric chloride was used by Homberg in 1705 and by De Boissiew in 1967.The use is commonly called kyanizing.

Copper sulphate recommended by De Boissiew and Bordenava in 1967 and best known as margaryzing.

Chloride of zinc recommended in 1815 by Thomas Wade and by Boucherie in 1837 and referred as burnettizing (Samuel B. Boulton, 1885)

The treatment of green timber with creosote by first using steam followed by a vacuum prior to impregnation with the oil is attributed to Hayfor (Jornal of Franklin institute, 1878).

Oily liquids preservatives used earlier

Creosote oil, carboleneum, shale oil used as wood preservatives in 1848 suggested by Hutin and Boutigny in 1848. 
The chemicals recommended in the year and used in various countries

CHEMICALS
Creofixol
$\begin{aligned} & \text { Creosote oil }+ \text { coal tar }+ \\ & \text { petroleum }\end{aligned}$
Creosite

YEAR

1919

1920

1922

\section{Metallic compounds}

\begin{tabular}{|l|}
\hline CHEMICALS \\
\hline Mercury chloride \\
\hline Copper sulphate \\
\hline Aczol \\
\hline Boliden salt \\
\hline Chromate zinc chloride \\
\hline Zinc sulphate \\
\hline Florine \\
\hline
\end{tabular}

\begin{tabular}{|l|l|}
\hline YEAR & COUNTRY \\
\hline 1705 & \\
\hline 1838 & Europe \\
\hline 1907 & Belgium \\
\hline 1932 & Scotland \\
\hline 1934 & USA \\
\hline World war 2 & \\
\hline $19^{\text {th }}$ century & \\
\hline
\end{tabular}

\section{Inorganic compounds}

Boron compound - used as fire retardants in wood (1933).

Chromium compound - used as admixtures in water soluble preservatives salts (1938).

\section{Organic compounds}

Chlorinated phenols, Chlorinated cresols and xylonols, Chlorinated napthalenes (1913), Nitrated phenols and cresols- $19^{\text {th }}$ centuries, Chlorinated benzenes (1940 onwards), dichloro diphenyl-trichloroethane (DDT), Organic mercury compounds (Brosevan Groenou et al., 1952).

\section{Preservatives used presently}

Oil and oil borne preservatives used are the Coal tar, creosote solution, petroleum fuel oil.

The principal toxic chemical used is pentachlorophenol. It has very low solubility in water and low volatility and is very stable chemical therefore it is most promising and widely used preservatives of oil borne chemical type. Demerits - It has been found ineffective against marine borers and never used for the protection of wood in salt water. Waterborne preservatives used are arsenic salt, borax and boric acid, chromium salt, cupper sulphate, mercuric chloride, nickel salt, sodium chloride, zinc chloride

Demerits - These are highly toxic to the human body and animal. (Ref:-Gorge $\mathrm{M}$. Hunt and George A. Garratt 1953)

In European country wood preservatives are used -

In England creosoting is most popular method, in Germany creosote and zinc chloride are extensively used. In France the timbers and poles are impregnated with copper sulphate, in United states modern preservation begins in the country in 1875 creosoting is the popular method (Howard F. Wiess).

In United States zinc chloride, creosote, coaltar, carbonelium salt. The production of low temperature coal tar, creosote in 1950 was negligible in the USA but in England it 
was used. The incising of poles is confined to northern white cedar and western red cedar and also for Douglas fir, wastern larch (American Wood Preservers Association, 1916 handbook on wood preservation). Living tree can be treated by preservatives like Banding method, Capping method, Stepping method, Pitch treatment of standing trees.

Non pressure process used for preservation are Dipping method, Steeping method, Kyanizing, other methods used are cold soaking, hot and cold bath, diffusion processes (George M. Hunt and George A. Garratt, 1953). Copper compounds are used as preservatives. Cation exchange capacity test on some lignocellulosic material highlight some aspect of the use copper as wood preservatives (Sttaccioli et al., 2000).

The greatest impact on wood preservation in the $20^{\text {th }}$ century is the invention of chromated copper arsenate (CCA) preservatives by Sonti Kamesam in India in the 1930's. It involved development of a product that balanced needs for availability of active biocides against invading organisms with stability against leaching. It served the industry extremely well, long before mechanisms of fixation and other environment and health related issues were well understood or appreciated.

In Canada the predominant wood preservative chemicals or formulations are as follows-

Aqueous based formulations for residential use:

ACQ (alkaline copper quaternary) - ACQtreated products include lumber for patios and fencing in residential construction.

CA-B (copper azole) - CA-B-treated products include lumber for patios and fencing in residential construction

Borates - Uses are for wood components in interior applications.
Aqueous based formulations for commercial and industrial use:

CCA (chromated copper arsenate) - CCAtreated products include agricultural fence posts, foundation lumber and plywood, utility poles and construction timber. Chromated copper arsenate (CCA) is used in pressuretreated wood to protect it from dry rot, fungi, molds, termites, and other pests. This wood is used in decks, wooden playground equipment, picnic tables, gazebos, bridges, and other outdoor wood products. In May 2001, the Environmental Working Group petitioned the Consumer Product Safety Commission to ban the use of CCA-treated wood in playground equipment (Dr Champaign Illinois Sustainable Technology Center).

ACZA (ammonical copper zinc arsenate) ACZA treated products include marine structures and construction timbers. At the time of publication, this preservative was not in use in Canada.

Oil based formulations for commercial and industrial use:

PCP (pentachlorophenol) - PCP-treated products include utility poles and cross-arms.

Creosote - Uses include treatment of railway ties, utility poles for export, and pilings and timbers for marine applications.

The development of alternative chemicals for wood preservation is the subject of ongoing research. The use of alternative chemicals will depend on industry and safety evaluations, and on approval under the Pest Control Products Act (PCPA), administrated by Health Canada's Pest Management Regulatory Agency (PMRA).

In India the preservatives used mostly are creosote, pentachlorophenol, CCA, CCB, ACC, boric acids and borax. A number of 
compositions like ASCU, ASCU boric (CCB), pentachlorophenol aldrin, creosote are available in India. Fire retardant treatment of plywood, fibre board is also carried out by the chemical composition which is recommended in Indian standards (Arnon, 1965 and 1980; Satish Kumar and Indra Dev, 1993).

\section{Technology involved in wood preservation}

Drying - Drying increases preservative penetration and also ensures, for larger timbers and roundstock, that much of the checking occurs before treatment. If timber is not adequately dried there is the risk that these checks might subsequently extend into untreated wood when the timber is in service.

Incising - Douglas fir, larch and spruce, are very resistant to the penetration of preservatives and can only be pressure treated effectively if incised. When treating poles, incisions can be concentrated on the region close to the groundline, so putting the preservative where it is most needed.

Steaming or Boultonizing processes - In the steaming process. green wood is steamed in a pressurised treating cylinder for several hours. usually at a maximum temperature of $118^{\circ} \mathrm{C}$ $\left(245^{\circ} \mathrm{F}\right)$ so that the outer annulus of wood is heated above $100^{\circ} \mathrm{C}$.

Vacuum/pressure impregnation treatments These techniques result in deep penetration of permeable timbers while at the same time controlling the amount of preservative Retained.

Modified full cell or 'low weight' method

Vacuum treatments - In this process atmospheric pressure may be thought of as the pressure period. Vacuum treatments have been commonly used for treatment of dry profiled or machined components (millwork) using preservatives carried in light organic solvents. Sonic waves are used in pressure treatment of Douglas fir and ponderosa pine and the result indicate that sonic waves more significant potential for the improvement of pressure treating process and the treatment of refractory wood (Nair and Simonsen, 1995).

\section{Wood modification}

The durability of wood can be improved through wood modification, this can be achieved through:

Heat treatment

Accetylation (accoya)

Furfurylation

Silicone/silane

Oil /wax /paraffin

Melamine resin

Thermowood: chemicals are not used, Temperature $180^{\circ} \mathrm{C}$ to $220^{\circ} \mathrm{C}$. Producers are Finland, Netherland, Russia, France, Germany

Acetylation: Impregnation with acitic anhydride, reaction at elevated temperature, post treatment with acitic acid acetylated wood is dimensionally stable and resistant to rot. Its durability remains unchanged and the timber split less than untreated wood ex: accoya wood.

Furfurylation: Is the pressure treatment of wood with a solution of furfuryl alcohol made from bio mass waste after drying and hardening the reselt is hard heavy and dimensionaly stable timber are obtain that is resistant to rot.

Silicon impregnation: The method uses no biocides or fungus inhibiting preparation insted imitating the natural fossilisation process that occurs in inorganic material such as wood as they turn into fossils. 
(www.woodarchitecture.se/knowledge/choose -the-right-wood-preservation.)

\section{Plasma treatment}

It is a versatile and powerful technique: by producing high frequency electric discharges, plasma generates 'ionised' gas that can change the surface properties of the material it is in contact with. Bugnicourt says the consortium looked at plasma treatments as they can either 'hydrophobic' (waterproof) wood surfaces or makes them more compatible with waterborne coatings. the plasma pre-treatment a costefficient, durable, and environmentally friendly technology, could add five to seven years life to the wood.

\section{Pleot-electro pulsing technology for wood protection}

If PLEOT is installed, the moist wooden material conducts electric current. This selfregulating typical areas of application for impregnated wood are terraces, construction materials, cladding, playgrounds, noisedeflection walls, guardrails, telephone poles. In addition, the technology can be applied to protect wooden windows and doors. System consumes a minimal amount of power and can for instance be run by a solar panel.

It is likely to conclude that the PLEOT system was influencing not only the directly connected samples but also the untreated samples since the untreated samples were in the same soil and container as the treated ones. The PLEOT system could thereby lower the mass loss of the untreated samples. New test setup is necessary to verify these results.

Average mass loss of CCA- and PLEOTtreated and untreated Scots pine samples (Pinus sylvestris) after 32 weeks in soil contact; the samples showed a wood moisture content after the test of 124 (11) \% PLEOT,
$100(21) \%$ and 165 (14) untreated (Treu and Larnøy, 2010).

\section{Environmental causes of preservatives}

Various wood preservatives developed by TsNIIMOD organisation in Russia and which do not contain chlorophenols. The preservatives are k-1 (main toxic ingredients organic compounds of aliphatic series), EOK, K-12(F SALTS) and Katan (Varfolomeev, Yua, 1995).

In 1978, the united state environmental protection agency (USEPA) uses three preservatives for the treatment of lumber creosote, inorganic arsenical and pentachlorophenol (penta). But after some years pentachlorophenol and arsenical are restricted as they are harmful to humans, these are declared as restricted use pesticides (Patrick J Marer and Mark Grimes, 1992).

Cca treated wood should never be burned, as the smoke particle inhaled and can be toxic. 3 (Dobbs and Grant, 1978).

Nymphs of Potamanthus luteus were found in Kymijoki River, Southern Finland in 1997. The nymphs collected from the badly contaminated site had generally darkened gills, possibly indicating impacts of pollution (Vuori, 1999). In 2003 the Environmental Risk Management Authority of New Zealand conducted an extensive independent review of CCA-related cancer risk estimate studies which included five major studies conducted subsequent to the updated As human cancer potency factor developed by the National Academy of Science's Natural Research Council in 2001 (Helena Solo-Gabriele, 2004).

The presence of some types of inorganic ions in water has been reported to increase leaching from CCA treated wood, Water $\mathrm{pH}$ 
can also affect leaching of preservatives. Leaching of CCA is greatly increased when the $\mathrm{pH}$ of the leaching water is lowered to below 3, and the wood itself also begins to degrade. Most controlled leaching trials of preservative treated wood samples to leaching via immersion. Immersion is perhaps the simplest type of leaching mechanism to control and replicate, and it provides a severe leaching environment (Stan Lebow et al., 2004).

Wood preservatives can be harmful to humans if not properly handled. The exposure routes by which they can enter the human body are inhalation (vapour, dust, aerosol, etc.), ingestion (solid, liquid), ocular exposure and through the skin (vapour, liquid, solid). A number of studies have examined the effects of wood preservatives on settlement patterns, growth and biomass development of human of environments. The majority of leaching from wood when treated with waterborne preservatives, The rate and overall amount of leaching from a given product is also affected by preservative penetration and retention and by the surface area of the product.

\section{Strategies}

The current international trends are to:

1) Use less preservative, through use of alternative materials such as concrete ties, other materials for poles, use of untreated wood and movement to wood modification (chemical and thermal) to protect wood.

2) Decrease the accepted limits of pesticides in drinking water, surface water, soil, sediments, food etc. This makes it more difficult to comply with regulations and guidelines at all stages of the life cycle for certain preservatives.

3) Reduce use of arsenic, chromium, creosote and pentachlorophenol containing preservatives and probably in the longer term, copper containing preservatives. In parallel with this, the trend is for introduction of a much broader suite of alternatives, with main focus on organic preservatives.

4) Increase reliance on incineration for disposal of most spent wood including treated wood.

For example, in 1991, Japan incinerated $40 \%$ of its waste wood (Honda et al., 1991). Holland and Germany (by 2005) will both ban landfilling of waste containing more than a specified amount of organic material (Peek 1999).

5) Recover inorganic preservatives from treated wood by collecting and treating ashes and condensate from co-generation or incineration facilities (Italy and Finland).

6) Require manufacturers to take full life responsibility for their products.

In conclusion, the great variety of wooddestroying insects and fungi in tropical countries constitutes a much greater danger for timber used in such areas elsewhere in the world. High temperature and high atmospheric humidity, together with the extraordinarily large number of nondurable wood species, render timber in the tropics particularly vulnerable to decomposition.. Consumption of sawnwood and wood used in the round is expected to rise considerably in the tropics during the period from 1961 to 1975. The expected growth rate (70 percent) is likely to be more than three times higher there than in the rest of the world.. The value of timber used in tropical countries as sawnwood and roundwood amounted to approximately $\$ 2100$ million in 1966 (Swiderski). A considerable proportion of this value could be saved annually through expanding the preservation treatment of 
wood. The average cost of preservation may amount to 25 to 35 percent of the initial value of the wood and ensures a service life of not less than three to five times that of untreated timber. The average investment costs for establishing a pressure-treatment plant are low (\$5 per cubic metre per year); this makes it possible to establish the necessary capacities with a comparatively small capital expenditure and over a short period of time Wood preservation makes it possible to reserve precious durable species for export markets by replacing them on local markets with less durable but properly treated timbers. It is also a necessary condition for export trade in many wood products which are vulnerable to damage by fungi or insects. In many countries where naturally durable species are nearing depletion, utilization of properly treated secondary species constitutes the only way in which the utilization of wood in most of its applications can be maintained.

\section{References}

Baltimore American wood preservers association 1916 handbook on wood preservation.

Brosevan Groenou, H. et al., (1952) wood preservation during the past 50 years IInd edition.

Dobbs, A.J. and C. Grant. 1978. the volatisation of arsenic on burning cupper chromate arsenic treated wood holzforchung 32(1).

Gorge M. Hunt and George A. Garratt 1953 wood preservation II edition.

Helena Solo-Gabriele February 8-11, 2004 Florida Center for Environmental Solutions Gainesville, Florida Environmental impacts of Preservative-treated wood.

Kevin Archer and Stan Lebow 2006,Chemical Specialties, Inc., Charlotte, North Carolin USA; 2USDA Forest Products
Laboratory, Madison, Wisconsin, USA.

Nair, H.U., Simonsen, J. 1995. The pressure treatment of wood with sonic waves, Forest Product J. USA. 45(9)59-64.

Patrick J Marer, Mark Grimes 1992 University of California Integrated Pest Management Program, Wood Preservation Volume 3 of Pesticide application compendium Volume 3335 of Publication [University of California (System). Division of Agriculture and Natural Resources)].

Primary Wood Processing Principles and Practice, Chapter 9, 2nd edition, 2006; pp 297-338.

Samuel B. Boulton. 1885. Preservations of timber by the use of antiseptic", Journal of Franklin institute, 1878.

Satish Kumar and Indra Dev1993wood preservation in India FRI Dehradun.

Stan Lebow, Paul Cooper, Patricia Lebow February 8-10, 2004 Variability in Evaluating Environmental Impacts of Treated Wood.

Sttaccioli, G., Sturarro A., Rella, R. 2000. Holzforschung 54(2): 133-136.

Swiderski, J. September/October 1967. Importance of wood preservation in tropical countries lecture on the subject delivered by the Chief of the FAO Forest Industries and Utilization Branch, at the International Seminar on Wood Preservation in Tropical Countries, sponsored by FAO/IUFRO/DSE (Deutsche Stijtung für Entwicklungsländer) at Feldafing near Munich, September/October 1967.

The 1995 Wood Preserving Industry Production Statistical Report, American Wood Preservers Institute, Vienna, VA, September 1996.

Treu, A. and E. Larnøy 9-13 May 2010Wood protection by means of electro osmotic pulsing technology (PLEOT) The 
Norwegian Forest and Landscape Institute.

Varfolomeev, Yua. 1995. Reducing the ecological danger of wood preservatives, Derevoobrabaty vayushchaya promyshlennost NO 3,10-11[Ru] TSNIIMOD, Russia.

Vuori, K,M. (1999). Entomologica fennica notes on the morphology and 10(3): 171-174.
Wood preservation manual 1986 food and agriculture organisation of the United Nations Forestry. Pp. 76.

www..fpl.fs.fed.us/documnts/pdf2006 /fpl_2006_archer001.pdf).

www.ec.gc.ca/pollution/default.asp?lang=En $\& \mathrm{n}=226 \mathrm{C} 285 \mathrm{~F}-1 \&$ offset=3\#p1s3.

\section{How to cite this article:}

Sonia Panigrahi and Sadhna Tripathy. 2019. Enhancement of Technology from Old Preservatives to New Preservatives and Latest Development in the Field of Preservation. Int.J.Curr.Microbiol.App.Sci. 8(01): 2173-2182. doi: https://doi.org/10.20546/ijcmas.2019.801.227 